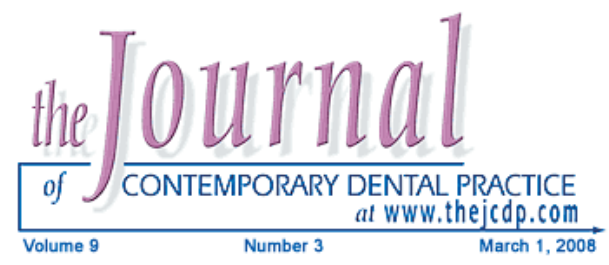

\title{
Review of Over-the-counter Treatments for Aphthous Ulceration and Results from Use of a Dissolving Oral Patch Containing Glycyrrhiza Complex Herbal Extract
}

\author{
Jeff Burgess, DDS, MSD; Peter van der Ven, DMD, PhD; \\ Michael Martin, DMD, MA, MPH, MSD, PhD; \\ Jeffrey Sherman, PhD; Jeff Haley, BA, BS, JD
}

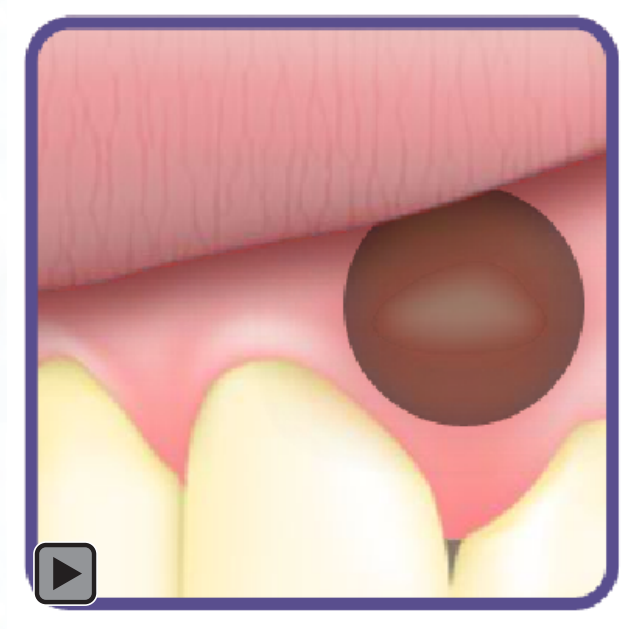

Abstract

Aim: The aim of this article is to present a review of over-the-counter (OTC) treatment strategies used for aphthous ulcerations and to provide results from the use of an herbal extract containing glycyrrhiza.

Background: Aphthous ulceration, a disease of the intra-oral mucosa, is a common condition of unknown etiology that is often self-managed by OTC (no prescription required) medication.

Review: Preparations currently on the market can be divided into several categories: local anesthetic agents, oxygenating agents, mouth rinses, and barriers - further subdivided into paste coverings such as gels or dissolvable or non-dissolvable adhesive patches containing plant extract or synthetic drugs. Other strategies include herbs, hematinic replacement, or off-label OTC drug applications. While many OTC treatments are available and accepted for use with aphthous ulceration, a review of the literature via a number of published research search engines suggests that to date there are no randomized controlled studies to demonstrate OTC preparations do more than manage symptoms. Exceptions include OTC cyanoacrylate products and CankerMelts $^{\circledR}$ GX patches which include glycyrrhiza (licorice) extract. The use of CankerMelts has been shown to alter the course of the condition by reducing lesion duration, size, and pain.

(c) Seer Publishing 
Summary: The results of the studies reviewed here suggest CankerMelts GX discs may be as effective as amlexanox (which must be prescribed) in reducing pain and speeding healing. In addition it can be applied by the patient without the adverse events associated with cyanoacrylate formulations.

Keywords: Aphthous ulcerations, glycyrrhiza, cyanoacrylate

Citation: Burgess J, van der Ven P, Martin M, Sherman J, Haley J. Review of Over-the-counter Treatments for Aphthous Ulceration and Results from Use of a Dissolving Oral Patch Containing Glycyrrhiza Complex Herbal Extract. J Contemp Dent Pract 2008 March; (9)3:088-098.

\section{Introduction}

Aphthous ulceration, a disease involving erosion of the intra-oral mucosa, is a common condition of unknown etiology that can produce considerable pain and discomfort, altered speech, and altered masticatory function in those affected. It is characterized by the presence of one to several rounded, shallow ulcers of varying sizes that are localized most commonly on the buccal and labial mucosa, floor of the mouth, and ventral tongue. Lesions typically persist from seven-14 days and heal without scarring. They may reoccur, sometimes frequently, but typically in different locations. Recurrent aphthous ulceration (RAU) affects approximately $20 \%$ of the adult population of the United States. ${ }^{1}$ Three types of RAUs are described in the literature: minor, major, and hepetiform. ${ }^{2}$ The minor aphthous ulcer is typically shallow and less than 1 centimeter in diameter with a necrotic center covered by a grey or yellow pseudomembrane. This lesion type is estimated to represent approximately $75-85 \%$ of all RAU lesions. ${ }^{3} \mathrm{~A}$ major aphthous lesion is typically larger, deeper, and persists longer than its minor counterpart (i.e., up to four weeks). It is also more painful and heals with scarring, a clinical finding used to distinguish between the 'minor' and 'major' subtypes.

While RAU in an otherwise healthy person is not likely to be associated with significant complications, a number of more serious systemic diseases and immune disorders may confound or contribute to aphthous-like oral ulcerations. These include, among others, HIV infection, Behcet's disease, lupus, pharyngitis, cyclic neutropenia, hematinic deficiencies, and gastrointestional disease. ${ }^{2,4,5}$

Patients with oral lesions and more generalized symptoms that suggest multisystem disease

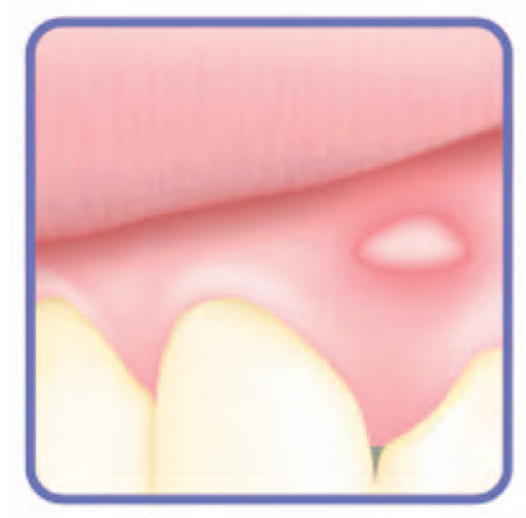

should be referred for an additional workup. However, even with medical referral, a recommendation for over-the-counter (OTC) management of ulceration in the interim prior to additional consultation is reasonable.

\section{Over-The-Counter (OTC) Products}

OTC management strategies for oral ulceration currently on the market can be divided into the following categories:

- Those covering the lesion and providing a barrier. These are further subdivided into:

- those using a paste covering,

- those using a film-forming gel covering,

- those using a dissolvable or non-dissolvable adhesive patch, with or without an additional medicinal formulation (e.g., plant extract or synthetic drug).

- Local anesthetic agents

- Oxygenating agents

- Mouthrinses

- Other strategies (e.g., the use of herbs, hematinic replacement, or off-label OTC applications)

Barrier techniques not utilizing additional drugs are considered to be devices by the US Food 
and Drug Administration (FDA) because the therapeutic effect is thought to be achieved via mechanical means versus the metabolic or chemical action of an incorporated drug or other formulary (Table 1).

\section{Local Anesthetics}

The majority of commercially available products contain benzocaine in variable percentages (e.g., $6.4 \%$ to $20 \%$ ). In two OTC preparations (i.e., Orabase-B (Colgate Oral Pharmaceuticals,

Table 1. Product types.

\begin{tabular}{|c|c|}
\hline Type & Therapeutic Agent \\
\hline Barrier Pastes & $\begin{array}{l}\text { - Orabase } \\
\text { - Orabase B (benzocaine 20\%) } \\
\text { - Honey }\end{array}$ \\
\hline Bioadhesive Discs & $\begin{array}{l}\text { - CankerMelts GX* (Glycymhiza extract) } \\
\text { - Carrington Orapatch (aloe vera hydrogel) } \\
\text { - Canker Cover } \\
\text { - Orajel protective mouth sore discs (benzocaine) }\end{array}$ \\
\hline Film-forming Gels & $\begin{array}{l}\text { - Orabase Soothe-N-Seal } \\
\text { - Zilactin } \\
\text { - Zilactin-B (benzocaine } 10 \% \text { ) } \\
\text { - Kank-A (benzocaine } 20 \% \text { ) }\end{array}$ \\
\hline $\begin{array}{l}\text { Local Anesthetics } \\
\text { (benzocaine) }\end{array}$ & $\begin{array}{l}\text { - Orabase-B (benzocaine } 20 \% \text { ) } \\
\text { - Kank-A (benzocaine 20\%) } \\
\text { - Zilactin B (benzocaine 10\%) } \\
\text { - Senso-gard (benzocaine } 20 \% \text { ) } \\
\text { - Tanac (benzocaine } 10 \% \text {, benzalkonium chloride } 0.12 \% \text { ) } \\
\text { - Anbesol Gel (benzocaine } 6.4 \% \text { and .5\% phenol) } \\
\text { - Oralief } \\
\text { - Orabase-B Gel (benzocaine } 15 \% \text { ) } \\
\text { - Medadyne } \\
\text { - Orajel protective mouth sore discs (benzocaine) } \\
\text { - Hurricaine Liquid and Gel (Benzocaine 20\%) }\end{array}$ \\
\hline Oxygenating Agents & $\begin{array}{l}\text { - Orajel perioseptic } \\
\text { - Amosan (Sodium Perborate Monohydrate) } \\
\text { - Peroxyl mouthrinse } \\
\text { - Peroxyl Oral Spot Treatment Gel ( } 1.5 \% \text { hydrogen peroxide in gel base) } \\
\text { - Cankaid Rinse (carbamide peroxide } 10 \% \text { ) } \\
\text { - Gly-Oxide (carbamide peroxide } 10 \% \text { ) } \\
\text { - Periolav (carbamide peroxide } 10 \% \text { ) } \\
\text { - Orajel Perioseptic (carbamide peroxide } 15 \% \text { ) }\end{array}$ \\
\hline
\end{tabular}


Table 1. (Cont.) Product types.

\begin{tabular}{|c|c|}
\hline Type & Therapeutic Agent \\
\hline $\begin{array}{l}\text { Other Antiseptic Mouth } \\
\text { Rinses }\end{array}$ & $\begin{array}{l}\text { - Chlorhexidine* } \\
\text { - Chiorheximed* } \\
\text { - Triclosan } \\
\text { - Benzydamine hydrochloride } \\
\text { - Diflam* } \\
\text { - Oraldene } \\
\text { - Listerine } \\
\text { - Viadent } \\
\text { - Plax } \\
\text { - Biotene mouthwash (antibacterial enzymes) }\end{array}$ \\
\hline Herbs & $\begin{array}{l}\text { - CankerMolts } G X^{*} \text { (Glycymhiza extract) } \\
\text { - Many others }\end{array}$ \\
\hline Off-Label Applications & $\begin{array}{l}\text { - Zinc gluconate lozenges } \\
\text { - Hydrogen peroxide } \\
\text { - Sulcralfate paste } \\
\text { - Diphenhydramine Hydrochloride (Benadryl syrup) with Kaopectate and } \\
\text { Maalox }\end{array}$ \\
\hline
\end{tabular}

* Products with reported controlled studies

Canton, MA, USA) and Zilactin B (Blairex Laboratories, Inc., Columbus, IN, USA) benzocaine is delivered at $20 \%$ and $10 \%$, respectively. In liquid or gel form, the anesthetic may also be combined in other formulations that may also contain alcohol, phenol, saccharin, carbomer 934P, potassium iodide, camphor, glycerin, menthol, polyethylene glycol, propylparaben, methylparaben, benzalkonium chloride, sorbitan mono-oleate, tannic acid, and other components. Examples include the following:

- Sensogard ${ }^{\circledast}$ (Block Drug Company, Inc, Jersey City, NJ, USA)

- Tanac ${ }^{\boxplus}$ (Del Pharmaceuticals, Uniondale, NY, USA)

- Anbesol ${ }^{\boxplus}$ Gel (Wyeth Consumer Healthcare, Madison, NJ, USA)

- Oralief, ${ }^{\text {TM }}$ Orabase $-B$ Gel (Colgate Oral

Pharmaceuticals, Inc., Canton, MA, USA

The concentration of alcohol can vary from $0.5 \%$ (Anbesol Gel) to 70\% (Anbesol Liquid). ${ }^{6}$ Other
OTC topical anesthetics contain benzoin tincture, camphor, and phenolor as active ingredients.

While these specific anesthetic OTC formulations are available and accepted for use with aphthous ulceration, review of the literature via a number of published research search engines suggests there have been no randomized controlled studies assessing their efficacy in the management of aphthous ulceration to date. The most that can be stated with respect to the effect of these substances on oral aphthous is these products may be effective in reducing pain for a brief period of time after application when used during the course of normal ulcer healing. There is no evidence that they shorten healing time or reduce the duration of pain during the clinical course of the disease.

Adverse reactions and side effects associated with the use of these anesthetics include allergy (e.g., hives, burning, stinging, skin rash, or itching), interaction with other medications - 
particularly in the elderly, where overuse may potentially lead to excessive absorption, and subsequent neurologic abnormality (e.g., blurred vision, confusion, convulsions, dizziness, drowsiness, headache, perceived change in body temperature, restlessness, etc.). A number of web-based sites are available to aide the patient in proper usage. ${ }^{7}$

\section{Oxygenating Agents}

Oxygenating preparations include oral rinses such as:

- Biotene ${ }^{\circledast}$ mouthwash (Laclede, Inc., Rancho Dominguez, CA, USA)

- Orajel $^{\oplus}$ Perioseptic ${ }^{\circledast}$ (Del Pharmaceuticals, Inc., Uniondale, NY, USA)

- Amosan ${ }^{\circledast}$ (Oral-B Laboratories, lowa City, IA, USA)

Biotene has been extensively studied as a treatment strategy for xerostomia but has also been recommended for use with aphthous ulceration. However, to date there are no published studies supporting its use in this context. Nonetheless, two key proteins purified from bovine colostrums used in Biotene, lysozyme and lactoferrin, have demonstrated antimicrobial (but not necessarily 'oxygenating') effects that may be helpful in preventing super infection at the ulcer site.

The action of Orajel Perioseptic (carbimide peroxide) is unknown, ${ }^{8}$ but it is likely the effect may be bacteriocidal secondary to oxygenation of the mucosal tissue. No studies in relation to aphthous treatment have been reported.

Amosan contains sodium perborate monohydrate buffered with sodium bitartrate. This oxidizing agent, with and without additional antimicrobials (chlorhexidine), has been found to reduce tooth plaque and gingivitis ${ }^{9,10}$ suggesting it could also have an inhibitory effect on secondary bacterial colonization. A bad 'taste' seems to be the only side effect noted with its use.

\section{Mouthrinses}

A number of other OTC oral rinses have been listed as useful in managing aphthous ulcerations including the following:

- Difflam ${ }^{\circledast}$ (3M Health Care Ltd., Loughborough, UK) containing benzydamine hydrochloride
- Listerine ${ }^{\circledast}$ (Johnson \& Johnson via McNeil Consumer Healthcare, Fort Washington, PA, USA)

- Viadent ${ }^{\boxplus}$ (Colgate Oral Pharmaceuticals, New York, NY, USA)

- $\operatorname{Plax}^{\circledast}$ (McNeil Consumer Healthcare, Fort Washington, PA, USA)

- Oraldene ${ }^{\circledast}$ (McNeil Consumer Healthcare, Fort Washington, PA, USA)

Of the above products, benzydamine hydrochloride (Difflam, shown in Figure 1) is the only one that has been extensively studied (Table 2).

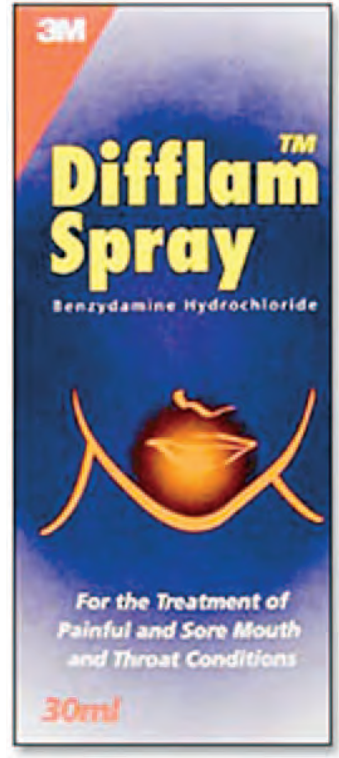

Figure 1. Difflam spray packaging.

Benzydamine is classified as a prostaglandin inhibitor. Utilized in a randomized controlled trial $(\mathrm{RCT})$ involving 18 subjects, it has been reported as being effective in producing transient pain relief when used in the management of aphthous stomatitis. ${ }^{11}$ However, its use has not been reported to improve healing. ${ }^{12}$ In one study assessing the effect of benzydamine on an ulceration associated with placement of orthodontic hardware, results suggested the rinse is no more effective than a placebo in reducing the incidence, severity, and duration of oral pain following orthodontic appliance placement. ${ }^{13}$

Adverse reactions associated with the use of benzydamine hydrochloride have included 
Table 2. Reported studies involving OTC products.

\begin{tabular}{|c|c|c|c|c|c|}
\hline $\begin{array}{l}\text { Author \& Year } \\
\text { Published }\end{array}$ & OTC Product & Typo of Study & $\mathbf{N}$ & Rosults & $\begin{array}{l}\text { Side Effects/ } \\
\text { Adverse } \\
\text { Reactions }\end{array}$ \\
\hline $\begin{array}{l}\text { Asher, Shaw } \\
1986\end{array}$ & $\begin{array}{l}\text { Berzydamine } \\
\text { hydrochloride } \\
\text { Q. } 15 \% \text { (Difflam) } \\
\text { used as needed to } \\
\text { maximum of three } \\
\text { times hourly }\end{array}$ & $\begin{array}{l}\text { Placebo controlled four } \\
\text { wook tinal in fixed } \\
\text { orthodontic appliance } \\
\text { pationts }\end{array}$ & $\begin{array}{l}39 \text { active; } 29 \\
\text { placebo }\end{array}$ & $\begin{array}{l}\text { No difference for } \\
\text { soreness days, } \\
\text { overage maximum } \\
\text { pain scores, and } \\
\text { report of screness }\end{array}$ & $\begin{array}{l}\text { Tingling or } \\
\text { burning following } \\
\text { use }\end{array}$ \\
\hline $\begin{array}{l}\text { Matunews ot al } \\
1987\end{array}$ & $\begin{array}{l}\text { Berzydamine, } \\
\text { Chlonexicine ard } \\
\text { pacebo } \\
\text { mouthwashes }\end{array}$ & $\begin{array}{l}\text { Random orter use, } 3 \\
\text { months each formulation } \\
\text { (9 months total) }\end{array}$ & 18 & $\begin{array}{l}\text { No significart } \\
\text { afferences beween } \\
\text { treatments for } \\
\text { outcome measures }\end{array}$ & $\begin{array}{l}\text { Stinging dunng } \\
\text { application }\end{array}$ \\
\hline $\begin{array}{l}\text { Hurter, Addy } \\
1987\end{array}$ & $\begin{array}{l}\text { Chlorhexidine } \\
\text { (Corsody) } 0.2 \% \\
x \text { day }\end{array}$ & $\begin{array}{l}\text { Double-blind. placebo } \\
\text { (quinine sulfate)-controlled } \\
\text { cross-over trial } \\
\text { (two } 6 \text { week tx periods with } \\
\text { a } 3 \text { week washout interval) }\end{array}$ & 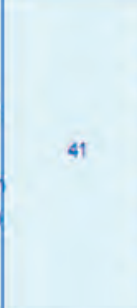 & $\begin{array}{l}\text { Reduction in } \\
\text { rumber of ulcer-free } \\
\text { cays; pain severity } \\
\text { scores not } \\
\text { significant between } \\
\text { active and placobo } \\
\text { goups; duration } \\
\text { unaffected by } \\
\text { treatment }\end{array}$ & $\begin{array}{l}\text { Not reported in } \\
\text { this study, but } \\
\text { reportod } \\
\text { proviously by } \\
\text { Addy, ot al } \\
\text { (1982) as brown } \\
\text { staining }\end{array}$ \\
\hline $\begin{array}{l}\text { Edres. Scully, } \\
\text { Golbier } 1997\end{array}$ & $\begin{array}{l}\text { Benzycamine with } \\
\text { Chlorhexicine }\end{array}$ & $\begin{array}{l}\text { Open Label Uncontrolled } \\
\text { with } 38 \text { agents. }\end{array}$ & so & $\begin{array}{l}\text { Difllam } \\
\text { (Berzydamine } \\
\text { hydrectionide and } \\
\text { Corsodyl } \\
\text { (CWiomexidine } \\
\text { Gluconate) } \\
\text { mouthwash gave } \\
\text { some symptomatic } \\
\text { relief }\end{array}$ & Not reported \\
\hline \multirow[t]{2}{*}{$\begin{array}{l}\text { Kutcher, et al } \\
200 \text { s }\end{array}$} & \multirow[t]{2}{*}{$\begin{array}{l}\text { Cyanoscrylate with } \\
\text { Orapatch }\end{array}$} & $\begin{array}{l}\text { Placebo controlled tilals } \\
\text { Two Phases: } \\
\text { Phase 1-Applied by } \\
\text { investigator. Two } \\
\text { formulations + sham } \\
\text { saline }\end{array}$ & 42 & $\begin{array}{l}\text { Formula } 1 \\
\text { sigrificantly } \\
\text { reduced healing } \\
\text { time (6.9 vs. } 8.8 \\
\text { days): Formula } 1 \\
\text { produced sigrificart } \\
\text { short-tem pain } \\
\text { reduction (4.60 vs. } \\
5.64 \text { ) }\end{array}$ & $\begin{array}{l}\text { Inikial discomfort } \\
\text { and irritation or } \\
\text { burning }\end{array}$ \\
\hline & & $\begin{array}{l}\text { Phase } 2 \text { - Subject } \\
\text { application: rormulation } 1 \\
\text { (cyanoacrylate), versus } \\
\text { hycrogel with aloe ven } \\
\text { versus sterle water }\end{array}$ & 155 & $\begin{array}{l}\text { No Significant } \\
\text { dfference between } \\
\text { groups tor time to } \\
\text { healing. Treatment } \\
\text { groups had } \\
\text { significant pain } \\
\text { reduction }\end{array}$ & $\begin{array}{l}\text { Initial discomfon } \\
\text { and irntation; } \\
\text { difficulty placing } \\
\text { treatments }\end{array}$ \\
\hline Martin, et al 2007 & $\begin{array}{l}\text { Ucorice patch } \\
\text { (CankerMets) with } \\
\text { no treatment }\end{array}$ & $\begin{array}{l}\text { Placebo controlled trial } \\
\text { with patch delivered } 18 \\
\text { hours after first sign of } \\
\text { aphthous lesion }\end{array}$ & $\begin{array}{l}23 \text { active: } 23 \\
\text { no treatment }\end{array}$ & $\begin{array}{l}\text { Significant } \\
\text { afference between } \\
\text { treatment and no } \\
\text { treatment for } \\
\text { stimulated and } \\
\text { prestimulus pain } \\
\text { ft ter } 3 \text { days: } \\
\text { significant } \\
\text { differenco in ulcer } \\
\text { size at soven days }\end{array}$ & None reported \\
\hline
\end{tabular}


photocontact dermatitis, ${ }^{14}$ allergy (e.g., rash, itching, throat spasm, shortness of breath), oral numbness and stinging, ${ }^{15}$ and in laboratory studies cytoxicity. ${ }^{16}$

Listerine, containing menthol, thymol, methyl salicylate, eucalyptol, as well as alcohol (from $21-26 \%$ ), is typically used as an antiseptic mouthwash. It has also been suggested as potentially useful in the management of aphthous ulceration, presumably because of its known antimicrobial properties. Unfortunately, there is no supportive evidence for this specific use. In general, Listerine use is not associated with significant side effects or adverse reactions. Its allergy potential appears to be minor. There is one reported fatality associated with massive ingestion of a phenol-based mouthwash (nearly three liters) ${ }^{17}$ which is not likely to occur with prudent short-term use in the management of aphthous ulcerations.

Additional mouthrinses that have potential utility but lack scientific support include Viadent, which contains sanguinaria; Plax, which includes sodium benzoate and sodium lauryl sulfate; and Oraldene containing $0.1 \%$ hexetidine. While the above mouth rinses are generally safe and not usually associated with adverse effects, sodium retention may be a problem with the use of some products (Viadent, Plax, and Cepacol $\left.{ }^{\circledR}\right){ }^{18}$

Another oral rinse which is discussed here because it is available OTC in countries other than the United States for treating oral ulcerations is chlorhexidine. ${ }^{19,20,21}$ Chlorhexidine has demonstrated efficacy in reducing oral bacterial counts, and this feature could be beneficial in preventing super-infection as previously described (Table 2). In the Hunter et al. ${ }^{20}$ study a rinse of $0.2 \%$ chlorhexidine diluted in five milliliters of water and used three times a day resulted in an increase in the number of ulcer free days, but pain severity scores were not found to be significantly different between the active and placebo groups and the duration of lesions was unaffected by treatment. Adams et al. ${ }^{22}$ provide a good overview of the various mouth rinses available for use as anti-plaque agents that might also be useful with aphthae. Their comprehensive monograph underscores the lack of science behind the general recommendation for OTC mouth rinses (with the exception of chlorhexidine) to treat aphthous ulceration. In contrast, a webbased review of five randomized controlled trials assessing chlorhexidine gluconate or similar preparations conclude outcome measures generally improve during the use of these rinses during clinical trials. ${ }^{23}$

\section{Other Strategies (Herbs, Hematinic Replacement, and Off-Label OTC Applications)}

\section{Herbs}

The above oral rinse therapeutic strategies appear to be those most commonly recommended for aphthous ulcerations. However, a general Internet search is telling with respect to the number of other untested products on the market that are touted as helpful in treating oral ulceration. For example, there is 'Myrrh extract' which is recommended as an anti-infectious agent formulated from commiphora myrrha. There is also Mo Yao, an herbal oleo-gum resin that is said to be 'antiseptic to mucous membranes, and, curiously, both inhibits over-secretion as well as disinhibits under-secretion of these tissues' and is touted as being able to 'normalize mucous membrane activity'. Other herbs recommended as helpful to treat canker sores include agrimony, chamomile, cranesbill, echinacea, goldenseal, oak, periwinkle, tormentil, witch hazel, aloe vera, and licorice extract (particularly as modified with acid to precipitate glycyrrhizin, called DGL). ${ }^{24}$

Of these herbs, only licorice extract has been rigorously studied with the results suggesting support for its application (see below). There is also 'Ora5' (McHenry Laboratories, Edna, TX, USA), reported to be useful because it incorporates copper sulfate and iodine, the

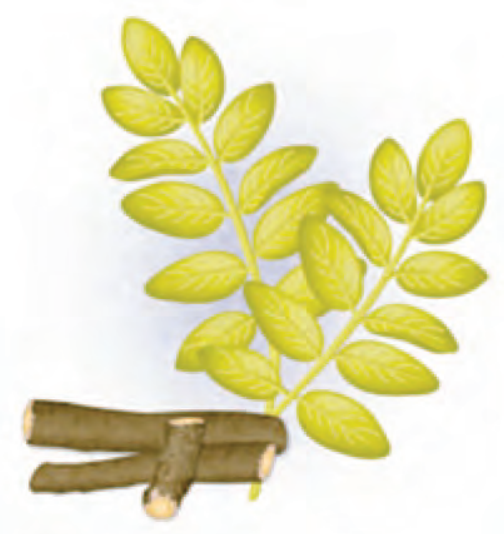


'oldest natural ingredients known to man', that presumably act similarly to antibiotics to 'reduce superficial soreness and infection'. ${ }^{25}$ With the exception of licorice extract (Table 2), use of the above herbal formulations is unsupported by controlled or randomized/controlled trials.

\section{Hematinic Replacement}

While hematinic deficiency is not currently considered a primary cause of aphthous stomatitis, when a deficiency of iron, folic acid, or vitamin B12 is identified in a patient with aphthae, replacement therapy has been recommended. ${ }^{26,27,28}$ However, a number of studies suggest replacement therapy may not be particularly helpful. In one recent randomized, double-blind, placebo-controlled study reported by Kolseth et al. ${ }^{29}$ involving LongoVital (Pharmavita, Ltd., London, UK), an herbal-based tablet enriched with vitamins and other trace elements, no difference was found between the herbal and placebo groups in terms of treatment outcome. In another double blind, stratified-randomized clinical case-control study performed over six months, no significant difference in treatment outcome was found between placebo patients and those using replacement therapy (based on a $50 \%$ reduction in the number of ulcers and days in pain - considered by the authors as clinically relevant). However, in another report the number of aphthous ulcers per month is reported to have significantly decreased in a LongoVital treatment group. $^{30}$

\section{Off-label OTC Preparations}

Off-label strategies for utilizing various OTC medications, in individual or compounded preparations, are plentifully displayed using various web-based search engines. ${ }^{31}$ The interventions listed by these and other sites include: using a 'mild solution' of baking solution (not further defined), sucking on zinc gluconate lozenges, application of toothpaste, and use of diluted hydrogen peroxide (one part hydrogen peroxide and one part water applied with a cotton swab). Another intervention listed is the application of a paste formulated by a pharmacist mixing the combination of eight sulcralfate tablets (which need to be prescribed), $40 \mathrm{ml}$ sterile water, and three Ensure Variflavor Pacs (a flavoring product available in Canada) dissolved in $10 \mathrm{ml}$ sterile $\mathrm{H}_{2} \mathrm{O}$. Still another suggested compounded preparation involves OTC magnesium hydroxide antacid coupled with diphenhydramine hydrochloride $(5 \mathrm{mg} / \mathrm{ml})$. While all of the above (which cannot be purchased OTC) treatment strategies might provide limited benefit in reducing the pain associated with aphthae, there are no published studies documenting support for their use. The exception is the use of sulcralfate which has been documented as potentially useful by some studies. ${ }^{32}$

Topical corticosteroids, primarily hydrocortisone $1 \%$, although available OTC, should not be recommended for use with aphthae because in open label studies it has been shown such a low dose application is less effective and has less rapid onset than the more potent topical preparations that can be prescribed. In addition, off-label use of OTC corticosteroid has only been studied in terms of dermal application and not trials involving oral use. ${ }^{33,34}$

\section{Barrier Therapies}

There are several OTC products that offer a barrier method as treatment for aphthous ulcerations. These can be divided into those that utilize a paste, those that polymerize into an adhering film, and those that use a dissolvable or non-dissolvable patch. The latter are further subdivided into those containing no additional medication and those including some type of active ingredient.

\section{Paste Barriers \\ Paste preparations include Orabase ${ }^{\circledast}$ (Colgate Oral Pharmaceuticals, New York, NY, USA) and similar preparations made by compounding pharmacies. Orabase contains an emollient paste composed of sodium carboxymethyl cellulose, pectin, gelatin, sugar, cellulose, and tragacanth gum. These ingredients are contained in a plasticized hydrocarbon gel composed of $5 \%$ polyethylene in mineral oil. One formulation touted for pain relief also contains benzocaine (Orabase-B). \\ Ship et al. ${ }^{4}$ proposed the problem of intra- oral drug delivery, arising because viscous medications can be rubbed off or rinsed away by saliva, might be solved by compounding of these medications with mucosal adherents such as Orabase or isobutyl cyanoacrylate (Iso-Dent,}


Ellman Internationa, Oceanside, NY, USA). The implication is a person with aphthae could conceivably mix an OTC preparation of $1 \%$ hydrocortisone cream (note the above caveat) with Orabase paste or apply the corticosteroid to the mucosal tissue prior to application of a covering (e.g., Orabase or isobutyl cyanoacrylate). However, to date there are no studies assessing the relative effectiveness of these self administered approaches to delivery of OTC medication. Interestingly, in a small study ultilizing honey application compared with Orabase-B in the treatment of aphthous, no difference was found in ulcer size between these products, but honey use resulted in significantly greater pain relief than the use of Orabase-B. ${ }^{35}$

\section{Film Forming Gels}

The combination of topical anesthetic (benzocaine) with an alcohol suspended film forming a barrier includes Zilactin-B (Blairex Laboratories, Inc. Columbus, IN, USA) and Kank-A (Blistex, Inc., Oak Brook, IL, USA). Zilactin is a film-forming liquid composed of hydroxypropyl cellulose dissolved in 10\% benzyl alcohol. As the alcohol evaporates, the chemically modified cellulose forms bonds between molecules, resulting in an adherent film. It is recommended it be applied several times a day or as needed for pain relief.

Cyanoacrylate formulations ("super glue") form a film without using a solvent and have various medical applications. In the United States the only OTC cyanoacrylate product labeled for use on aphthous ulcers is Orabase ${ }^{\circledast}$ Sooth-N-Seal ${ }^{\circledR}$ (Colgate Oral Pharmaceuticals, New York, NY, USA) (Figure 2).

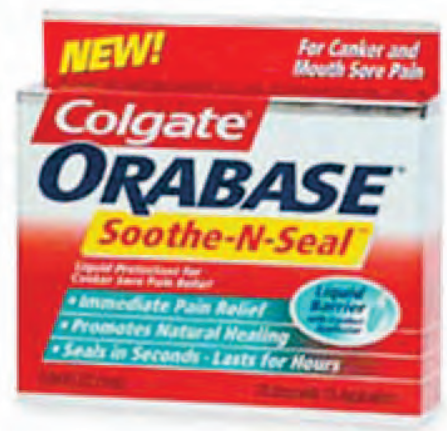

Figure 2. Orabase Soothe-nSeal packaging.
In one study ${ }^{36}$ two formulations of 2-octyl cyanoacrylate $(\mathrm{OC})$ tissue adhesives were tested against a sham material in 42 subjects. Application occurred twice on the initial day and once a day for an additional three days. It is reported that the average healing time for the two formulations was 6.9 (formulation one) and 7.5 (formulation two) days for these formulations and for the sham treatment 8.8 days. Only one of the cyanoacrylate formulations (number one undefined as to composition) was associated with a significant reduction in complete ulcer healing. One of the problems incurred during the study was sloughing of the cyanoacrylate membrane during the course of the day in some subjects. No other side effects are reported. In another study involving 40 subjects with two lesions, isobutyl cyanoacrylate was applied to one lesion and petroleum jelly to the other. It is reported that healing occurred on the fifth day of the trial for the majority of subjects using the cyanoacrylate versus the seventh day for those using petroleum covering. ${ }^{37}$

Kutcher et al. ${ }^{38}$ reports results of a two phase, randomized controlled study assessing pain reduction and healing time in the subjects. During phase one of the study, the subjects used two cyanoacrylate formulations and a simulated sham (the application of sterile saline). In phase two they used a formulation of cyanoacrylate compared with a control sham (sterile water) or a patch composed of freeze-dried hydrogel with aloe vera extract (Carrington Patch, Carrington Laboratories, Irving, TX, USA) (Table 2).

In phase one the examiner applied either the cyanoacrylate or the control vehicle four times a day until resolution of the ulcer pain; in phase two the products were self administered. The authors found with subjects using the two cyanoacrylate formulations (phase one) stimulated pain was significantly less in the device subjects than in those using saline. However, only one of the cyanoacrylate products was associated with significant long-term pain reduction (formulation \#1 - Closure Medical Corp., Raleigh, NC, USA) with the average mean number of days to complete cessation of pain 4.69 for formulation \#1, 4.85 days for formulation \#2, and 5.64 days for the sham saline. Mean time to no visible appearance of an ulcer was 6.9 days 
for formulation \#1, 7.5 days for formulation \#2 (Closure Medical Corp., Raleigh, NC, USA), and 8.8 days for the sham control. The only side effect noted was minor discomfort and 'stinging' or 'burning' pain with application of the device. In phase two short-term pain reduction was significantly better for subjects using the cyanoacrylate device and those using the Carrington Patch than for those using the control product. However, in contrast to phase one, in the second phase when subjects applied the devices themselves (versus examiner application), significant differences were not observed between control and device subjects in terms of long-term pain reduction or time to healing. Adverse effects reported during this phase included minor discomfort with cyanoacrylate application and difficulty in targeting the disk to the ulcer site (the device was reported to slide off and apparently failed to stay in place very well).

\section{Patch Barrier - Bioadhesive Discs}

Bioadhesive patch therapy, a relatively new and novel strategy devised for the treatment of aphthous stomatitis, has also been reported to be effective in reducing lesion size and pain. As previously noted, the Carrington Patch, composed of freeze dried polysaccharide hydrogel, was shown to be as effective as cyanoacrylate in reducing pain and lesion size in the Kutcher study. ${ }^{38}$ Mahdi et al. ${ }^{39}$ assessed the effect of a pharmaceutical grade cellulose patch on healing of aphthous ulcers. Patients were challenged by orange juice pre/post patch application and during the course of the study. Stimulated pain was said to be significantly improved after application of the patch. A patch composed of aloe vera hydrogel has been utilized in 31 pediatric patients aged six-14 years in an uncontrolled, open label study. ${ }^{40}$ Three or more patches were worn for four days. The authors report a significant reduction in stimulated pain and a positive therapeutic effect in $80 \%$ of cases, with positive improvement beginning within the second day of treatment.

Three patch devices sold OTC include Canker Cover $^{\oplus}$ (Quantum Health, Eugene, OR, USA), Orajel ${ }^{\oplus}$ Protective Mouth Sore Discs (Del Pharmaceuticals, Inc., Uniondale, NY, USA), and CankerMelts ${ }^{\oplus}$ (Orahealth Corp., Bellevue, WA, USA).
Canker Cover's ingredients include carbomer, hydroxypropyl cellulose, citrus oil, potassium magnesium chloride, ployvinylpyrrolidone K90 \& K25, xylitol, beta carotene, and coloring. For this product, it is recommended the patch be placed against the sore for 20 seconds. Within 30 minutes it becomes gel-like, and this state is said to last for up to eight hours before dissolving. Patches are applied as needed.

Orajel discs are composed of synthetic carbomer and pregelatinized zea mays (corn) starch coupled with benzocaine. The disc is to be placed against the lesion for five to ten seconds and reapplication may be repeated every two hours or four times daily.

CankerMelts (Table 2) is the only one of these three products that contains, in addition to the inactive ingredients collagen, hydrophilic gums and potassium, an active 'natural' ingredient: glycyrrhiza extract (GX) $30 \mathrm{mg}$ (licorice root extract). The disc is placed against the lesion for up to 60 seconds to gain adhesion. Discs, stated to last two to six hours, are to be placed periodically several times during the day until eight hours after the last symptom.

The Canker Cover packaging states the patch is 'clinically proven' but the research was uncontrolled. Subjects were given discs to use and asked whether they thought the healing time was reduced compared to what they remembered from prior untreated ulcers. Searching PubMed, the worldwide web, Google Scholar under "Orajel discs" did not reveal any published research assessing its efficacy to date. Adverse reaction to benzocaine includes allergy and potential interaction with other medications (as described above). Another potential problem with benzocaine combined with a gum patch is that it is a molecule that is not particularly water soluble. Because of this it may not effectively migrate through the disc. The result is a burst of anesthetic delivered to the ulcer initially and then, as the matrix dissolves, release from the non-adhered side of the disc causing generalized oral numbness, a feature that may not be well tolerated in some patients. According to a warning on the package, a Canker Cover disc may cause damage to the mucosa if it is removed before it naturally releases from the tissue. 


\section{Brief Report on a Clinical Trial Involving a Glycyrrhiza Oral Patch}

The results of an National Institutes of Health $(\mathrm{NIH})$ funded clinical trial of a dissolving oral patch (CankerMelts ${ }^{\circledR}$ shown in Figure 3 ) with an herbal anti-inflammatory, glycyrrhiza (licorice) extract utilized in a randomized, double blind, controlled efficacy study with outcome variables including stimulated and global pain score and lesion size is reported here.

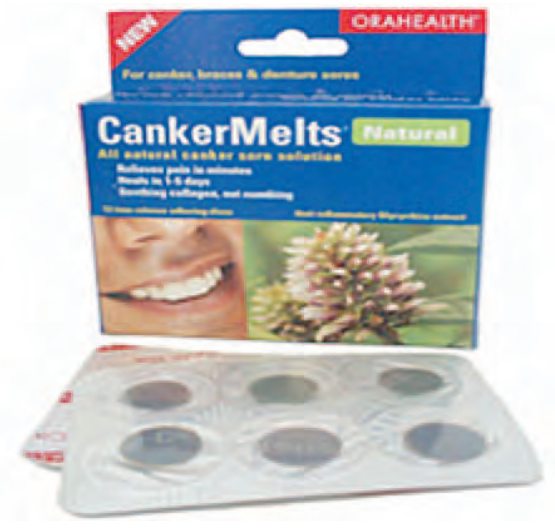

Figure 3. Cankermelts ${ }^{\circledR}$ packaging.

\section{Background}

The relative risk and safety of glycyrrihiza extract of licorice indicates it is neither teratogenic nor mutagenic, and the formulation is approved for use in foods by most national and international regulatory agencies. ${ }^{41}$ It has been widely used as an anti-inflammatory agent, ${ }^{42}$ and in one uncontrolled trial ${ }^{43}$ is reported to have provided pain relief in patients with aphthous ulcers. As noted, glycyrrhetinic acid has anti-inflammatory effects and also acts like a glucocortricoid and a mineralcorticoid. An analog of glycyrrhetinic acid is carbenoxolone (Biogastrone).

Carbenoxolone inhibits two enzymes important in the metabolism of prostaglandin. Further, although the exact responsible ingredients have not been determined, licorice extract is known to suppress some species of bacteria. It is possible this bacterial suppression also down-regulates immune system reactivity derived from bacterium protein adherence to the oral mucosa; an etiology that has been hypothesized as a cause of aphthous formation.

\section{Methods and Materials}

All subject selection, recruitment, and experimental procedures were approved by the
University of Washington Institutional Review Board. Adult subjects with a new occurrence of RAU were evaluated on days $1,3,4$, and 8 of an RAU episode. The treatment group (TG), $\mathrm{N}=23$, was instructed to use the patches 16 hours per day but not while sleeping and to keep usage logs (Figure 4). In a subsequent study using identical procedures and subject inclusion criteria, a no treatment (NT) control group $(\mathrm{N}=23)$ agreed to leave their lesions untreated. Subjects' pain reports, both unstimulated and stimulated (with a saturated saline swab), were noted at each visit. Ulcers were photographed at each visit, and ulcer size was calculated from photographs by a single examiner blinded to those receiving the active intervention.

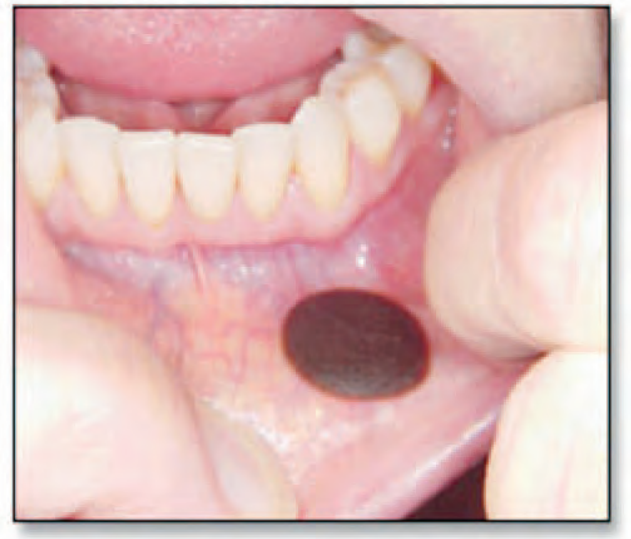

Figure 4. CankerMelts disc placed on the lip.

\section{Results}

At baseline, mean ulcer size was not significantly different between groups $\left(T G=3.1 \mathrm{~mm}^{2}\right.$, $\mathrm{NT}=2.3 \mathrm{~mm}^{2}$ ) although the size was somewhat greater in the treatment group, but by day eight (after seven days of treatment) visual ulcer size was significantly smaller in the TG than in the NT subjects $\left(T G=0.31 \mathrm{~mm}^{2}\right.$ versus $\left.2.6 \mathrm{~mm}^{2}, \mathrm{p}<.001\right)$.

Unstimulated and stimulated pain scores were not significantly different between groups at baseline, but by day four (after three days of treatment) both unstimulated and stimulated pain levels in the treatment group were significantly lower in the treatment group than in the untreated group (unstimulated: $p<.001$, stimulated: $p<.01$ ), and this difference persisted through day eight (unstimulated: $p, .01$, stimulated: $p<.01$ ). Usage logs revealed a mean usage of 8.4 hours per day with no adverse events reported. 
To our knowledge, this is the first controlled study utilizing a patch with glycyrrhiza extract to treat aphthous stomatitis, and the results suggest pain is significantly improved by the third day of treatment and visual lesion size is significantly improved by the seventh day of treatment. Adverse reactions and side effects were not reported by study participants.

\section{Discussion}

The importance of randomized controlled studies in establishing treatment efficacy cannot be overstated. Unfortunately, there is a dearth of such studies assessing OTC, herbal, or prescription formulations. To date, the extent of literature includes only a few RCTs (Table 2).

Kolseth et al. ${ }^{29}$ tested an herbal-based tablet enriched with vitamins and other trace elements but found no difference between the herbal and placebo groups. Kutcher et al. ${ }^{38}$ reports results of a randomized controlled study comparing pain reduction and healing time in subjects who used cyanoacrylate formulations vs. placebo. The authors found subjects using cyanoacrylate formulations reported lower stimulated pain and long-term pain reduction. Adverse events included minor discomfort with cyanoacrylate application and difficulty in targeting the material (defined as a gel) to the ulcer site. Further, significant effects in pain reduction were only found in participants when study personnel placed the device on the ulcer site. No significant pain reduction was found when participants placed the gel themselves.
Khandwala et al. ${ }^{44}$ report outcomes for a large vehicle-controlled, randomized, double-blind, parallel group, multicenter clinical study involving 1335 subjects who used amlexanox oral paste (Aphthasol ${ }^{\oplus}$, prescription required) to treat their aphthous ulcers. It is noted those treated with this product had complete resolution of pain within three to five days in one study location and three to eight days in another. In other locations subjects using amlexanox oral paste experienced significantly greater pain reduction and ulcer healing time than control subjects at days three to five (one location), three to six, three to eight, five to seven, and five to eight days (at the other locations).

The present controlled study demonstrated subjects receiving glycyrrhiza extract showed significantly decreased ulcer size after seven days of treatment and decreased unstimulated and stimulated pain scores after three days of treatment when compared to a no treatment group.

\section{Summary}

Taken together, the authors believe the results of these studies suggest glycyrrhiza extract may be as effective as amlexanox (which must be prescribed) in reducing pain and speeding healing. In addition it can be applied by the patient without the adverse events associated with cyanoacrylate formulations. 


\section{References}

1. Langlais RP, Miller CS. Color Atlas of Common Oral Diseases, Second Edition. 1998. Lippincott. Williams and Wilkins, Philadelphia.

2. Burgess JA, Johnson BD, Sommers E. Pharmacological management of recurrent oral mucosal ulceration. Drugs. 1990; 39(1):54-65.

3. Rogers RS, 3rd, Recurrent Aphthous Stomatitis, clinical characteristics and associated system disorders. Semin Cutan Med Surt. 1997; 16(4):278-283.

4. Ship J, Chevez E, Doerr P, Henson B, Sarmadi BS/M. Recurrent aphthous stomatitis. Quintessence Int. 2000; 31:95-112.

5. Porter SR, Scully C. Recurrent aphthous stomatitis. Crit Rev Oral Biol Med. 1998; 9:306-321.

6. Carpenter WM, Silverman Jr. S, Over-the Counter Products for Oral Ulcerations; J Calif Dent Assoc. 1998; March:1-5.

7. http://www.healthtouch.com. Date accessed October 1, 2007.

8. http://online.epocrates.com.and http://painhealth.com Date accessed November 13, 2007.

9. Wennstrom $\mathrm{J}$, Lindhe $\mathrm{J}$. Effect of hydrogen peroxide on developing plaque and gingivitis in man. J Clin Periodontol. 1979; 6(2):115-130.

10. Grundemann LJ, Timmerman MF, ljzerman Y, van der Weijden GA. Stain, plaque and gingivitis reduction by combining chlorhexidine and peroxyborate. J Clin Periodontol. 2000; 27(1):9-15.

11. Matthews RW, Scully CM, Levers BG, Hislop WS. Clincal evaluation of benzydamine, chlorhexidine, and placebo mouthwashes in the management of recurrent aphthous stomatitis. Oral Surg Oral Med Oral Pathol. 1987; 63:189-191

12. Jurge S, Kuffer R, Scully C, Porter SR. Mucosal diseases series, Number VI Recurrent aphthous stomatitis. Oral Diseases. 2006; 12:1-21.

13. Asher C, Shaw WC. Benzydamine hydrochloride in the treatment of ulceration associated with recently placed fixed orthodontic appliances. Eur J Orthod. 1986; 8(1):61-64.

14. Henschel R, Agathos M, Breit R. Photocontact dermatitis after gargling with a solution containing benzydamine. Contact Dermatitis. 2002; 47(1):53.

15. http://www.netdoctor.co.uk/medicines. Date accessed November 13, 2007.

16. Wilken R, Botha SJ, Grobler A, Germishuys PJ. In vitro cytotoxicity of chlorhexidine gluconate, benzydamine-HCL and povidone iodine mouthrinses on human gingival fibroblasts. SADJ 2001; 56(10):455-460.

17. Soo Hoo GW, Hinds RL, Dinovo E, Renner SW. Fatal large-volume mouthwash ingestion in an adult: a review and the possible role of phenolic compound toxicity. J Intensive Care Med. 2003; 18(3):160-162.

18. Wagner MJ, Tvrdy JL, Barnes GP, Lyon TC, Parker WA. Sodium retention from mouthwashes. Clin Prev Dent. 1989; 11(4):3-6.

19. Edres MA, Scully C, Gelbier M. Use of proprietary agents to relieve recurrent aphthous stomatitis. Br Dent J. 1997; 182(4):144-146.

20. Hunter L, Addy M. Chlorhexidine gluconate mouthwash in the management of minor aphthous ulceration. A double blind, placebo-controlled cross-over trial. Br Dent J. 1987; 162:106-110.

21. Addy M. Habitane in the treatment of aphthous ulceratiohn. J Clin Periodontol. 1977; 4(5):108-116.

22. Adams D, Addy M. Mouthrinses. Adv Dent Res. 1994; 8(2): 291-301.

23. http://www.clinicalevidence.com/ceweb/conditions/orh/1303/1303_I2.jsp. Date accessed September 13, 2007.

24. http://www.peacehealth.org/kbase/cam/hn-1180004.htm. Date accessed September 13, 2007.

25. http://www.edentalstuff.com/CankerSore.html. Date accessed September 13, 2007.

26. Jurge S, Kuffer, R, Scully C, Porter SR. Mucosal Diseases Series Number VI, Recurrent Aphthous Stomatitis. Oral Dis. 2006; 12:1-21.

27. Porter SR, Flint S, Scully, Keith O. Recurrent aphthous stomatitis: the efficacy of replacement therapy in patients with underlying haematinic deficiencies. Ann Dent 1992; 51:14-16.

28. http://www.emedicine.com/ent/topic700.htm. Date accessed, September 13, 2007.

29. Kolseth I, Herlofson BB, Pedersen A. Norwegian LongoVital and recurrent aphthous ulceration: a randomized, double-blind, placebo-controlled study. Oral Dis. 2005; 11(6):374-378. 
30. Bratel J, Hakeberg JM, Jontell M. The effect of LongoVital on recurrent aphthous stomatitis in a controlled clinical trial. Oral Health Prev Dent. 2005; 3(1):3-8.

31. http://www.medscape.com/viewarticle/546293; www.peacehealth.org/kbase/cam/hn-1180004.htm; www.clinicalevidence.com/ceweb/conditions/orh/1303/1303_I2.jsp; http://www.skin-disorders-guide. com/aphthous-ulcers.htm; www.pubmedcentral.nih.gov/articlerender.fcgi?artid=1439568; www.jada. ada.org/cgi/content/abstract/127/8/1202; www.prodigy.nhs.uk/aphthous_ulcer/extended_information/ management_issues; www.findarticles.com/p/articles/mi; www.laneshealth.com/soothagel; www.aafp.org/afp/20000701/149.html Date accessed September 13, 2007.

32. Rattan J, Schneider M, Arber N, Gorsky M. Sucralfate suspension as a treatment of recurrent aphthous stomatitis. J Intern Med. 1994, 236d(3):341-343.

33. Lozada-Nur, Huang MZ, Zhou GA. Open preliminary clinical trial of clobetasol propionate ointment in adhesive paste for treatment of chronic oral vesiculoerosive diseases. Oral Surg Oral Med Oral Pathol. 1991; 71:283-287.

34. Eisen D, Lynch D. Selecting topical and systemic agents for recurrent aphthous stomatitis. Cutis. $2001 ; 68: 201-206$.

35. Ashrafi S, Mastronikolas S, Wu C. Use of Honey in Treatment of Aphthous Ulcers. Abstract 1262, IADR 83rd General Session, March 9-12, 2005.

36. Ludlow J, Kutcher M, Samuelson A. Intraoral digital imaging documenting recurrent aphthous ulcer healing in 2-octyl cyanoacrylate versus sham-treated lesions. Oral Surg Oral Med Oral Pathol Oral Radiol Endod 2000; 89:425-431.

37. Hassan G, Ayoub A, el-Refaj M. A clinical trial on isobutyl cyanoacrylate as a protective adhesive in recurrent aphthous ulceration (RAU). Egyptian Dent J. 1984; 30:361-372.

38. Kutcher M, Ludlow J, Samuelson A, Campbell T, Pusek S. Evaluation of a bioadhesive device for the management of aphthous ulcers. J Am Dent Assoc. 2001; 132: 368-376.

39. Mahdi A, Coulter W, Woolfson A, Lamey P. Efficacy of bioadhesive patches in the treatment of recurrent aphthous stomatitis. J Oral Pathol Med. 1996; 25(8):416-419.

40. Andriani E, Bugli T, Aalders M, Castelli S, De Luigi G, Lazzari N, Rolli GP. The effectiveness and acceptance of a medical device for the treatment of aphthous stomatitis. Clinical observation in pediatric age. Minerva Padiatr. 2000; 52(1-2):15-20.

41. Isbrucker RA, Burdock GA. Risk and safety assessment on the consumption of Licorice root (Glycyrrhiza sp.), its extract and powder as a food ingredient, with emphasis on the pharmacology and toxicology of glycyrrhizin. Regul Toxicol Pharmacol. 2006; 46(3):167-192.

42. Aikawa Y, Yoshiike T, Ogawa H. Skin Pharmacol. 1990; 3(4):268-271.

43. Das SK, Das V, Guati AK, Singh VP. Deglycyrrhizinated liquorice in aphthous ulcers. J Assoc Physicians India. 1989; 37:647.

44. Khandwala A, Van Inwegen R, Alfano M. $5 \%$ Amlexanox oral paste, a new treatment for recurrent minor aphthous ulcers. Oral Surg Oral Med Oral Rathol Oral Radiol Endod. 1997; 83:222-230.

\section{About the Authors}

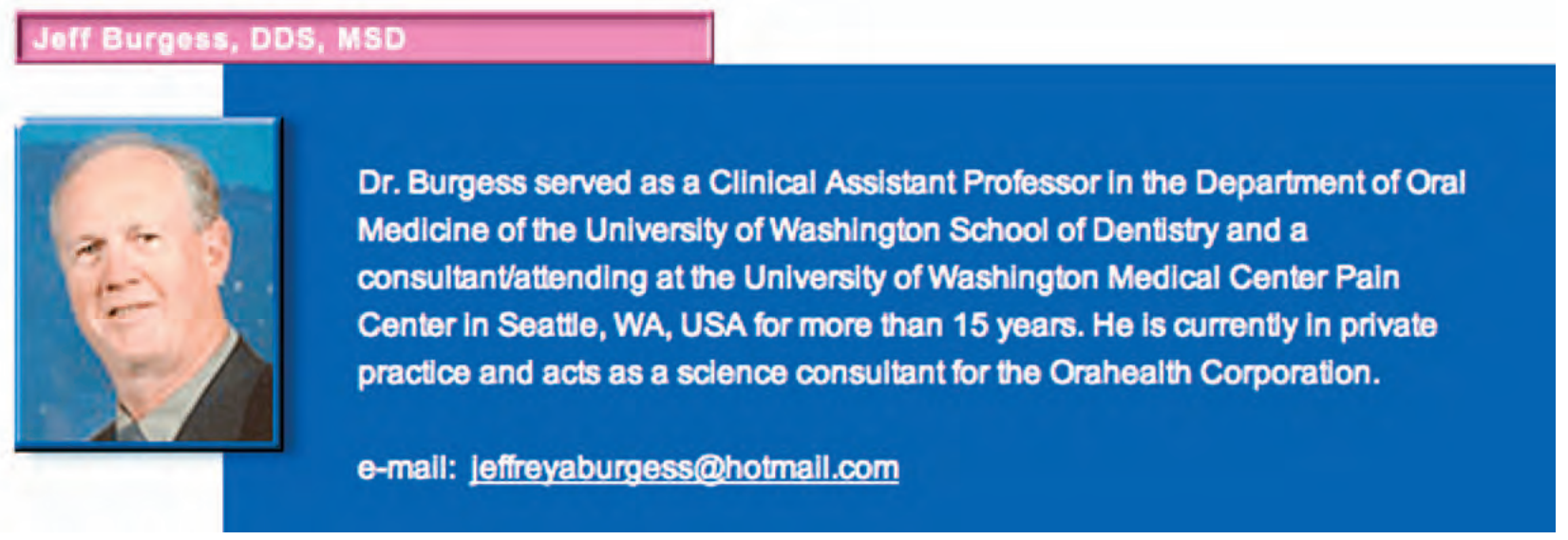




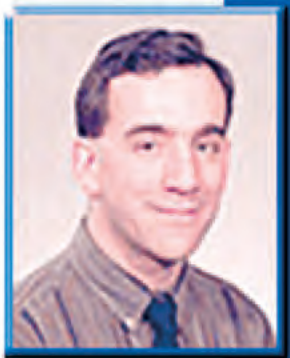

Dr. van der Ven serves as an Afflliate Instructor in the Department of Oral Medicine of the School of Dentistry at the University of Washington In Seattle, WA, USA. He recelved a certificate in Oral Medicine and a PhD in Oral Biology from the same institution and is board certified in Oral Medicine. Most of his time is currently spent in the private practice of Oral Medicine in Federal Way, WA, USA.

Michael Martin, DMD, MA, MPH, MSD, PhD

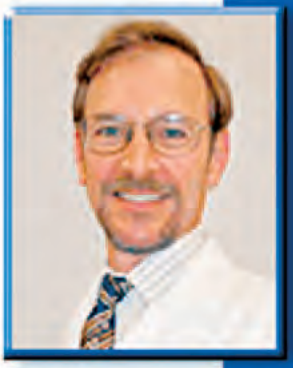

Dr. Martin is an Associate Professor in the Department of Oral Medicine at the University of Washington In Seattle, WA, USA. He recelved his dental degree from the University of Kentucky College of Dentistry then completed an MPH (1989), an MA In International Studies, a residency in Oral Medicine (1993), an MSD in Oral Medicine (1994), and a PhD in Epidemiology (1994), all at the University of Washington. He is board-certified in Oral Medicine, participates In a diverse research program and an active clinical practice of Oral Medicine within the University of Washington, School of Dentistry.

Joffroy Shorman, PhD

Dr. Sherman recelved a PhD in Clinical Psychology from the University of Kentucky in Lexington, KY, USA. He is a Clinical Assistant Professor in the Departments of Oral Medicine and Physical Medicine and Rehabilitation at the University of Washington.

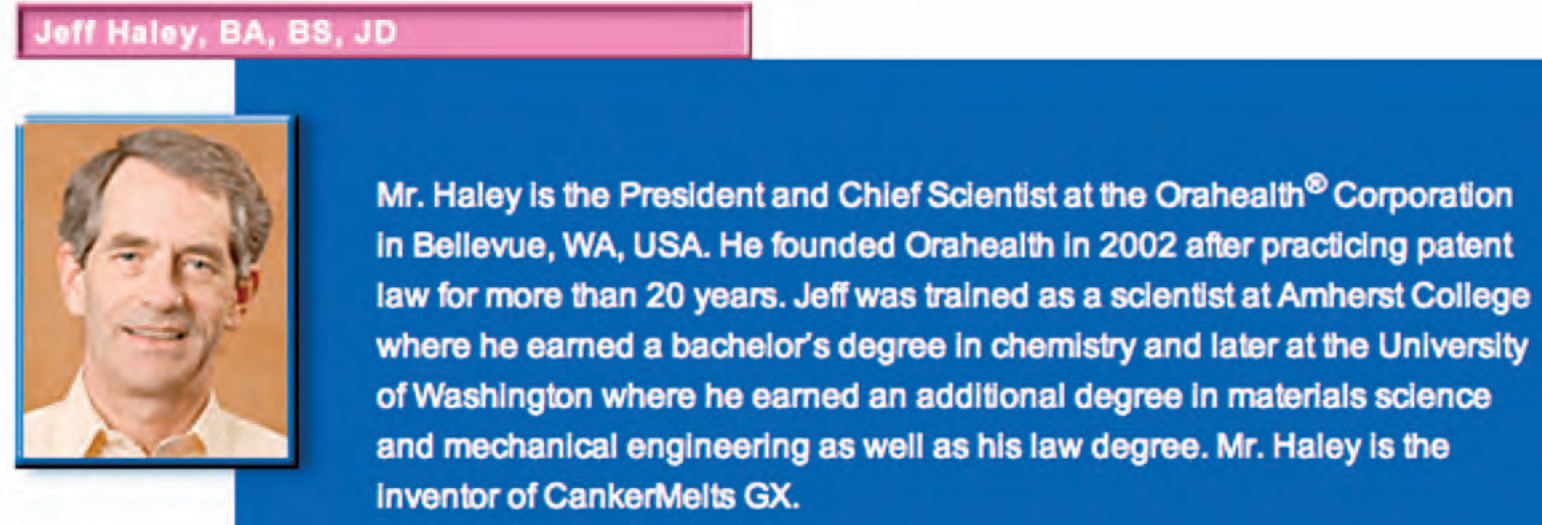

